\title{
APLIKASI SISTEM PENGIRIMAN BARANG EKSPOR BERBASIS WEB PADA PT TUNTEX GARMENT INDONESIA TANGERANG GUNA MENINGKATKAN MUTU PROSES PENGIRIMAN EKSPOR BARANG
}

\author{
Ruli Supriati ${ }^{1}$ \\ Agus Salim Saputra ${ }^{2}$ \\ Siti Shuhaibatul Islamiah ${ }^{3}$ \\ Dosen AMIK Raharja ${ }^{1}$, AMIK Raharja Jurusan Manajemen Informatika ${ }^{2,3}$ \\ Jl. Jendral Sudirman No. 40 Modern Cikokol - Tangerang, 15117, Indonesia. \\ E-mail:ㄹuli@raharja.ac.id, agus.saliml@raharja.info, Shuhaibatul@raharja.info
}

\begin{abstract}
ABSTRAK
PT. Tuntex Garment Indonesia adalah perusahaan besar yang bergerak dibidang garment khususnya berkerja sama dengan buyer international seperti NIKE yang terletak di Jl. Moch Toha KM 2 No. 29Tangerang. Perencanaan produksi dan penyiapan bahan baku adalah prosedur dalam pembuatan pakaian jadi. Jika pakaian jadi tersebut dianggap telah memenuhi syarat quality control (QC) yang dinyatakan diberikannya kode QC, maka department shipping akan mengeluarkan loading ekspor, pada pelaksanaanya dilimpahkan kepada warehouse (gudang finish good). Permasalahan yang dihadapi PT. Tuntex Garment Indonesia terutama pada bagian finish good dalam pencarian dan penyimpanan data atau document masih secara manual dengan membuka satu persatu arsip, sering terjadi kesalahan dengan membutuhkan waktu lama dalam menyiapkan data pengiriman. Maka perlu dirancang sistem informasi pengiriman barang ekspor berbasis web guna mengatasi permasalahan pada PT. Tuntex Garment Indonesia. Penelitian ini menggunakan metode pengumpulan data seperti, observasi, wawancara, studi pustaka adapun metode analisa sistem yang digunakan analisis SWOT dilanjut dengan perancangan berorientasi objek dengan menggunakan UML serta programming menggunakan Mysql sebagai database, PHP sebagai bahasa programnya. Hasil akhir penelitianadalah sebagai sistem informasi pengiriman barang ekspor sehingga memudahkan memperoleh informasi pengiriman dan pimpinan untuk melihat laporan kegiatan pengiriman barang ekspor.
\end{abstract}

Kata Kunci : Informasi, Gudang, Ekspor, Garment

\begin{abstract}
PT. Tuntex Garment Indonesia is a large company engaged in the garment especially in cooperation with international buyers such as NIKE located on Jl. Moch Toha KM 2 No. 29- Tangerang. Production planning and preparation of raw materials is a procedure in the manufacture of readymade garments. If the finished garment is deemed to have fulfilled the quality control (QC) requirement that the QC code provides, then the department shipping will issue export loading, in the execution delegated to the warehouse. Problems faced by PT. Tuntex Garment Indonesia especially on the finish of good in search and storage of data or document still manually by opening one by one archive, often happened mistake with long time in preparing data delivery. It is necessary to design a web-based export information delivery system to solve problems at PT. Tuntex Garment Indonesia. This research uses data collection methods such as, observation, interview, literature study as for system analysis method used SWOT analysis continued with object oriented design using UML as well as programming using Mysql as database, PHP as program language. The end result of the research is as an information system of export goods delivery so as to facilitate to obtain information of delivery and leadership to see report of export goods delivery activities.
\end{abstract}

Keywords : Information, Warehouse, Export, Garmen 


\section{PENDAHULUAN}

\section{LatarBelakang}

Informasi sangat penting untuk mendukung kelangsungan perkembangan, sehingga terdapat alasan bahwa informasi sangat dibutuhkan bagi suatu perusahaan. Teknologi dan informasi merupakan dua hal yang tidak dapat dipisahkan satu sama lain. Perkembangan teknologi yang pesat dalam perkembangan perangkat keras dan perangkat lunak serta teknologi komunikasi merupakan alternatif bagi suatu perusahaan untuk menunjung pengolahan data yang baik. Apabila pengolahan data tidak teratur dan tidak terkoordinasi dengan baik akan mengakibatkan sulitnya mengetahui data dan informasi secara tepat dan akurat.

Komputer merupakan alat bantu manusia yang sekarang ini memegang peranan penting dalam berbagai aspek kehidupan, khususnya dunia kerja. Mengingat begitu besarnya peranan informasi dalam pengambilan keputusan manajemenyang tepat diberbagai sektor tersebut, termasuk didalamnya sistem informasi dalam pengiriman barang yang ada di bagian gudang, harus mendapatkan perhatian yang serius dari waktu ke waktu. Persediaan barang jadi merupakan salah satu unsur kekayaan perusahaan Garment, disisi lain digunakan dalam rangka proses pengiriman barang ekspor production, gudang finish good dan shipping adalah tiga divisi dalam industri garment yang berperan dalam perencanaan persediaan dan pengiriman barang jadi dan mempunyai peranan yang sangat penting dalam menjalankan operasional pengiriman sehari-hari.

\section{Rumusan Masalah}

Berdasarkan latar belakang yang ada diatas yang telah dijelaskan maka,

Penulis merumuskan beberapa masalah sebagai berikut:

1. Bagaimanakah proses sistem informasi yang berjalan pada gudang ekspor PT. Tuntex Garment Indonesia?

2. Bagaimanakah kendala yang dialami pada sistem informasi gudang ekspor PT. Tuntex Garment Indonesia yang berjalan saat ini?

3. Bagaimanakah merancang sistem informasi pengiriman barang ekspor pada PT. Tuntex Garment Indonesia?

\section{Tujuan dan Manfaat Penelitian}

\section{Tujuan Penelitian}

Penulis mengelompokkan beberapa tujuan diantaranya sebagai berikut

1. Untuk mengetahui pelaksanaan sistem yang berjalan saat ini dalam melakukan aktivitas pengiriman barang ekspor pada PT. Tuntex Garment Indonesia.

2. Untuk mengetahui kendala yang dialami pada sistem informasi gudang ekspor PT. Tuntex Garment Indonesia yang berjalan saat ini.

3. Untuk merancang sistem informasi dalam melakukan proses pengiriman barang ekspor.

\section{Manfaat Penelitian}

Penelitian ini diharapkan dapat mempunyai berbagai manfaat, antara lain sebagai berikut: 
1. Dapat mengetahui pelaksanaan sistem yang berjalan saat ini dalam melakukan aktivitas pengiriman barang ekspor pada PT. Tuntex Garment Indonesia.

2. Dapat mengetahui kendala yang dialami pada sistem informasi gudang ekspor PT. Tuntex Garment Indonesia yang berjalan saat ini.

3. Dapat dihasilkannya rancangan sistem aplikasi berbasis web dalam memudahkan kegiatan pengiriman barang ekspor.

\section{Metodologi Penelitian}

Untuk mendapatkan data yang diperlukan dalam penelitian tersebut peneliti mengumpulkan beberapa metode sebagai berikut:

\section{Metode Analisa Kebutuhan PengumpulanData:}

\section{Observasi}

Suatu metode yang mengamati secara langsung kegiatan yang dilakukan divisi gudang pada PT. Tuntex Garment Indonesia yang terletak di Jl. Moh. Toha Km 2 No 29 Kel. Bugel Kec. Karawaci Kota Tangerang guna untuk mendapatkan data dan melakukan pencataan secara sistematis terhadap unsur yang diteliti.

2. Wawancara

Metode untuk mendapatkan data dengan mewawancarai secara lisan yang dilakukan kepada stakeholder yang bernama Muji Suwanto selaku Kepala Bagian Divisi Gudang.

3. Studi Pustaka

Pengambilan data yang diambil sumber tertulis yang bersangkutkan dengan penelitian yang berlaku

\section{Metode Analisa Data}

Setelah melakukan proses pengumpulan data kemudian data yang sudah diperoleh diolah dan dianalisa. Dalam melakukan perancangan sistem pengiriman barang ekspor peneliti menggunakan beberapa metode analisa yang dilakukan antara lain : Metode analisa SWOT.

\section{Metode Perancangan}

Dalam penelitian ini metode perancangan yang digunakan adalah pendekatan object oriented yaitu dengan menggunakan UML untuk merancang sistem yang baru, dimana diagram yang digunakan dalam penelitian ini adalah use case diagram, activity diagram, sequence diagram, class diagram dan state machine diagram.

Visual Paradigm for UML Interprise Edition, merupakan software yang akan digunakan untuk mendesign dan membuat suatu model diagram. PHP merupakan bahasa pemograman yang akan dipakai. XAMPP merupakan tool yang menyediakan paket perangkat lunak kedalam satu buah paket. MySQL merupakan database yang akan digunakan. Adobe Dreamweaver CS3, merupakan software yang digunakan untuk mendesign web yang akan dibuat.

\section{LANDASAN TEORI}

\section{Definisi Perancangan Sistem}

Menurut Hanik Mujiati dan Sukadi dalam indonesia Jurnal On Computer Science Speed (IJCSS) FTI UNSA Vol. 1 (2013:2088-0162) berpendapat bahwa, "Perancangan sistem adalah sebagai penggambaran, perencanaan dan pembuatan dari beberapa elemen yang terpisah kedalam satu kesatuan yang utuh dan berfungsi 


\section{Pengertian Sistem}

Menurut Aris, Dkk dalam jurnal SEMNAS TEKNOMEDIA Vol. 4 No. 1 2016: 23023805 "Sistem yang dapat didefinisikan dengan cara mengumpulkan, memproses, menyimpan menganalis, menyebarkan informasi untuk tujuan tertentu. Seperti sebuah sistem informasi terdiri atas input (data, intruksi) dan output (laporan, kalkulasi)".

\section{Definisi Informasi}

Menurut Rudy Tantra dalam bukunya yang berjudul Manajemen Proyek Sistem Informasi (2012:2) Berpendapat bahwa, "Informasi dapat dipahami sebagai pemrosesan input yang terorganisir, memiliki arti dan berguna bagi orang yang menerimanya. Data berbeda dengan informasi. Data dapat didefinisikan sebagai fakta-fakta yang masih mentah atau acak yang menjadi input atau untuk proses yang menghasilkan informasi.

\section{Definisi Web}

Menurut Murad, dkk dalam Jurnal CCIT Vol. 7 No. 1 (2013:49), "Website adalah sistem dengan informasi yang disajikan dalam bentuk teks, gambar, suara dan lainnya yang tersimpan dalam sebuah server web internet yang disajikan dalam bentuk hypertext.

\section{LITERATURE REVIEW}

1. Penelitian yang dilakukan oleh Faritno Juliansyah dengan judul "Mobile Aplikasi Pengiriman Barang Diintranet PT. Rinnai Indonesia". SKRIPSI STMIK RAHARJA (2013).

Pada penelitian ini menggunakan metode SWOT, menggunakan database MySQL. Aplikasi dalam penelitian ini dapat menyajikan informasi secara cepat, akurat dan relevan, dapat menghemat waktu untuk pencarian, pencatatan dan pemasukan data pengiriman barang serta dapat memudahkan dalam penyajian laporan kepada pimpinan.

2. Penelitian yang dilakukan oleh Asep Sofyan, Widia Dewi Astary dengan judul "Aplikasi Pengolahan Data Delivery Order di PT Sinamonas Industries". Jurnal Sisfotek Global ISSN: 2088-1762 Vol. 4 No. 1. Maret 2014. Pada penelitian ini dijelaskan bahwa perkembangan dunia teknologi informasi saat ini semakin cepat memasuki berbagai bidang, sehingga kini semakin banyak perusahaan yang berusaha meningkatkan usahanya terutama dalam bidang bisnis yang sangat berkaitan erat dengan teknologi informasi. Dimana dalam penggunaan komputer itu sendiri pada aplikasi bisnis ini adalah untuk menyediakan informasi dengan cepat dan akurat. Saat ini pada PT. Sinarmonas Industries proses penginputan delivery order masuk dan ekspedisi masih manual. Metode analisa rancangan yang digunakan adalah UML (Unifed Modelling Language). Bahasa pemograman menggunakan PHP, serta database yang diguanakan MySQL.

3. Penelitian yang dilakukan oleh Nur Dwi Santika dengan judul "Sistem Informasi Pengiriman Barang Berbasis Web Dengan Metode Transshipment". SKRIPSI Sekolah Tinggi Teknologi Tanjung Pinang (2014). Aplikasi ini berisi tentang Sistem informasi Pengiriman Barang berbasis web. Aplikasi ini dibuat untuk membantu sistem kerja pada perusahaan PCP, dimana Aplikasi ini menyediakan fasilitas-fasilitas yang menunjang kegiatan kerja yang sudah terkomputerisasi. Fasilitas-fasilitas yang disediakan oleh Aplikasi ini yaitu mencetak code number atau resi untuk pelanggan yang mengirimkan barang nya ke perusahaan PCP dan laporan perbulan pengiriman barang pelanggan. Memanfaatkan kecanggihan teknologi informasi guna menunjang kegiatan operasional pengiriman barang yang ada di PCP cabang tanjung pinang. 
4. Penelitian yang dilakukan oleh Abidin Zhu, Chao Zou, Wencheng Luo, Renjie Hedengan judul"The Demand-driven Conceptual Of Multi-Function Modular Cabinet For Medical Delivery Robot". Journal Procedia CIRP ISSN: 2212-8271 Vol. 53, 2016, Pages 273-277. Pada penelitian ini menyajikan sebuah aplikasi baru dari teori Axiomatic Design (AD) ke perangkat medis yang inovatif, lemari modular multi fungsi untuk pengiriman medis dirancang untuk mengantarkan berbagai persediaan medis bersamaan dengan mempertimbangkan tuntutan pengiriman multi fungsi dari instrumen bedah, organ, obat terlarang dan cairan di rumah sakit modern. Dengan menggunakan desain kabinet modular multi fungsi untuk membangun robot pengiriman prototipikal, teknik yang diusulkan terbukti mampu melakukan penyampaian multi fungsi dan konservasi sumber daya medis.

5. Penelitian yang dilakukan oleh Vitalii Naumov, Tatiana Omelchenkodengan judul"Model Of Delivery Routes Forming Process As A Service Provided By Forwading Companies". Journal Procedia Engineering ISSN: 1877-7058 Vol. 187, 2017, Pages 162-172. Dalam penelitian ini, mengusulkan sebuah pendekatan untuk memodelkan proses pengiriman barang melalui permintaan stokastik melalui pembentukan rute pengiriman yang rasional, yang bertujuan untuk mengembangkan model matematis pelayanan penerusan dengan menentukan faktor dampak dan lingkungan yang masuk, mengkarateristisasi elemen proses teknologi dan memberikan deskripsi analitis megenai hubungan antara parameter masukan dan kriteria efisiensi dalam bentuk fungsional. Model yang usulkan dapat menjadi dasar teoritis untuk pengembangan perangkat lunak pendukung keputusan untuk perusahaan pengangkutan barang.

\section{ANALISA SISTEM YANG BERJALAN}

\section{Gambaran Umum Objek Yang Diteliti}

Sistem yang berjalan pada PT. Tuntex Garment Indonesia berisikan beberapa prosedur-prosedur dimana prosedur ini dibuat menjadi beberapa kelompok prosedur. Sesuai dengan urutan penerimaan barang dan pengiriman barang yang berjalan saat ini pada PT. Tuntex Garment Indonesia adalah sebagai berikut :

1. Bagian Staff PC (Production Control) mengirim list data barang ke bagian produksi packing.

2. Bagian produksi packing menginput data actual barang, mengirim data dan barang ke bagian finish goods.

3. Bagian finish goods menerima, mengecek dan membuat laporan penerimaan barang yang dikirim dari produksi packing lalu melakukan proses pengiriman barang juga penginputan data penagihan forwarder yang diteruskan ke bagian accounting.

4. Bagian Accounting. mengecek data penagihan forwarder.

\section{Prosedur Pengiriman}

Bagian staff PC (Production Control)mengirim list data barang ke bagian produksi packing berupa print out data, lalu bagian produksi packing menerima hasil print out list data barang dari staff PC (Production Control), setelah itu produksi packing menginput data actual barang, mengirim barang dan data barang ke bagian finish goods.

Bagian produksi finish good menerima barang dan data dari produksi packing lalu mengecek barang tersebut sudah sesuai atau belum dengan list data barang yang mau dikirim, kemudian melaporkan hasil penerimaan barang dari produksi packing ke admin finish goods, admin finish goods menerima data dan menginput data penerimaan ke dalam 
microsoft excel, selanjutnya finish goods melakukan proses pengiriman barang berdasarkan instruksi dari pihak staff PC (Production Control). Setelah itu bagian finish goods melaporkan data pengiriman kepada admin finish goods dan adminfinish goods melaporkan data penagihan dari forwarder.

\section{Masalah Yang Dihadapi}

1. Sistem penginputan yang dilakukan oleh admin finish good PT. Tuntex Garment Indonesia masih kurang maksimal karena sebatas menggunakan aplikasi sederhana yaitu Microsoft Excel. Karena belum adanya sistem informasi yang mempermudah dalam laporan data pengiriman barang ekspor.

2. Susahnya mencari data pengiriman barang yang lama saat dibutuhkan.

3. Penyimpanan data pengiriman barang ekspor masih kurang tertata dengan baik, karena tidak adanya penyimpanan data terintegrasi. Sehingga masih terjadi kesalahan dalam posisi pengarsipan data pengiriman.

\section{Pemecahan Masalah}

Setelah meneliti dan mengamati beberapa permasalahan yang terjadi pada sistem berjalan, peneliti memberikan beberapa alternatif pemecahan masalah yang dihadapi, yaitu :

1. Membuat sistem berbasis web dengan menggunakan $M y S Q L$ sebagai database dan PHP sebagai bahasa pemogramannya, aplikasi yang dibangun berbasiskan web untuk memperoleh hasil maksimal.

2. Membuat sistem yang dapat memberikan laporan data pengiriman barang yang dapat dilihat setiap minggu, setiap bulan, maupun setiap tahun.

3. Membuat sistem terkomputerisasi yang dibutuhkan oleh admin finish good dengan meningkatkan pengontrolan data pengiriman barang menggunakan bahasa pemograman PHP.

\section{RANCANGAN SISTEM YANG DIUSULKAN DAN IMPLEMENTASI}

\section{Rancangan Sistem yang diusulkan}

Untuk rancangan sistem usulan ini berdasarkan dari prosedur sistem yang berjalan pada point. 3.2 yang digambarkan pada program Unifed Modelling Language (UML), terdiri dari Use Case Diagram, Activity Diagram dan Sequence Diagram. Tata laksana sistem yang berjalan digambarkan sebagai berikut: 


\section{Use Case Diagram yang diusulkan}

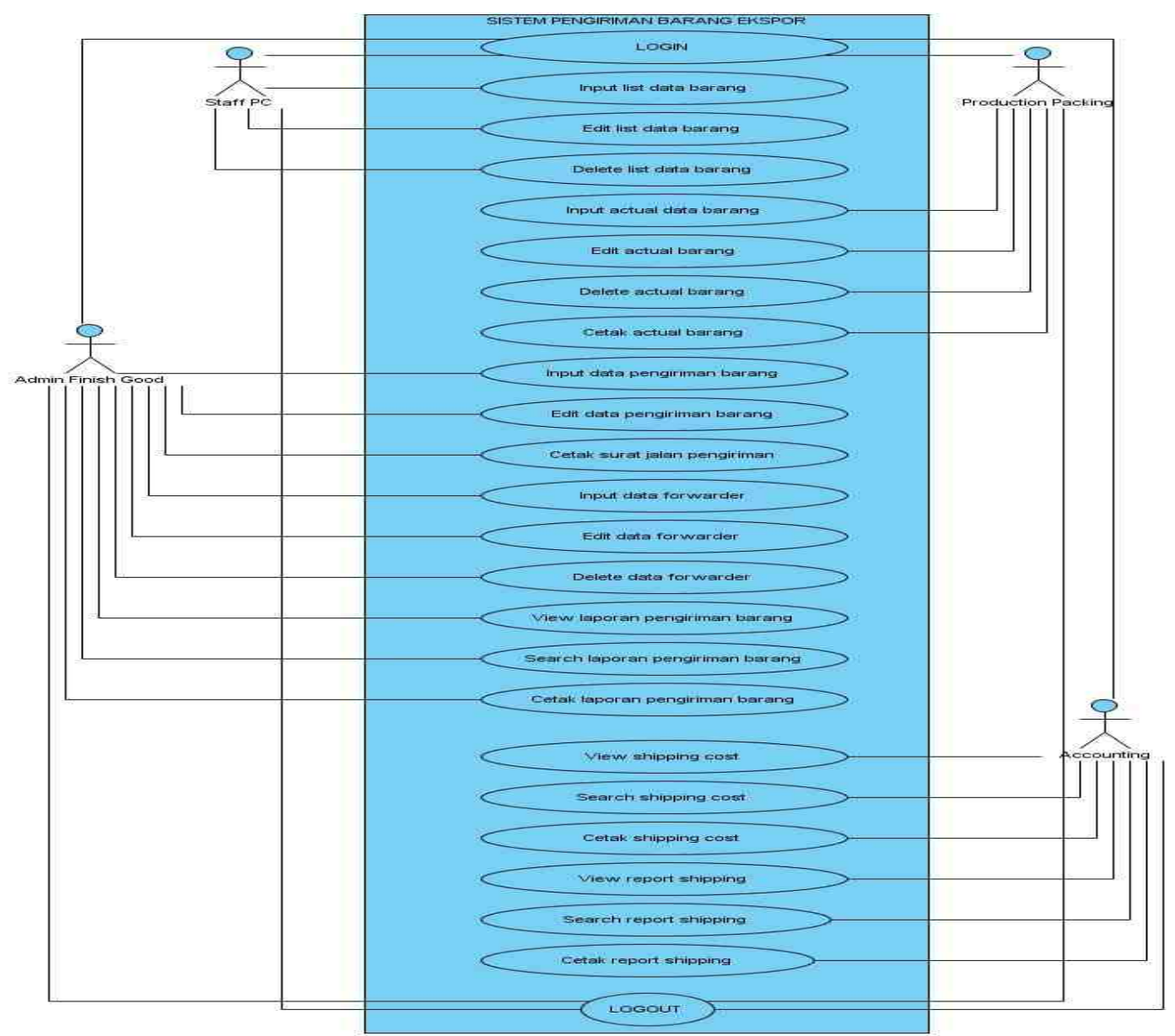

Gambar 1 Use Case Diagram Usulan

Berdasarkan Gambar 1 Sistem yang di usulkan saat ini terdapat :

1. 1 (Satu) sistem yang mencangkup seluruh kegiatan usulan pengiriman barang ekspor pada PT. Tuntex Garment Indonesia.

2. 4 (Actor) actor yang melakukan, yaitu Staff PC (Production Control), Produksi Packing, Finish Goods Dan Accounting.

3. Ada 24 (Dua Puluh Empat) Use Case yang dilakukan oleh actor-actor tersebut, diantaranya : login, input list data barang, edit list data barang, delete list data barang, input actual barang, edit actual barang, delete actual barang, cetak actual barang, input data pengiriman barang, edit data pengiriman barang, cetak surat jalan pengiriman, input data forwader, edit data forwader, edit data forwader, delete data forwader, view laporan pengiriman barang, search laporan pengiriman barang, cetak laporan pengiriman barang, view shipping cost, search shipping cost, cetak shipping cost, view report shipping, search report shipping, cetak report shipping dan logout. 


\section{Activity Diagram yang Di Usulkan}

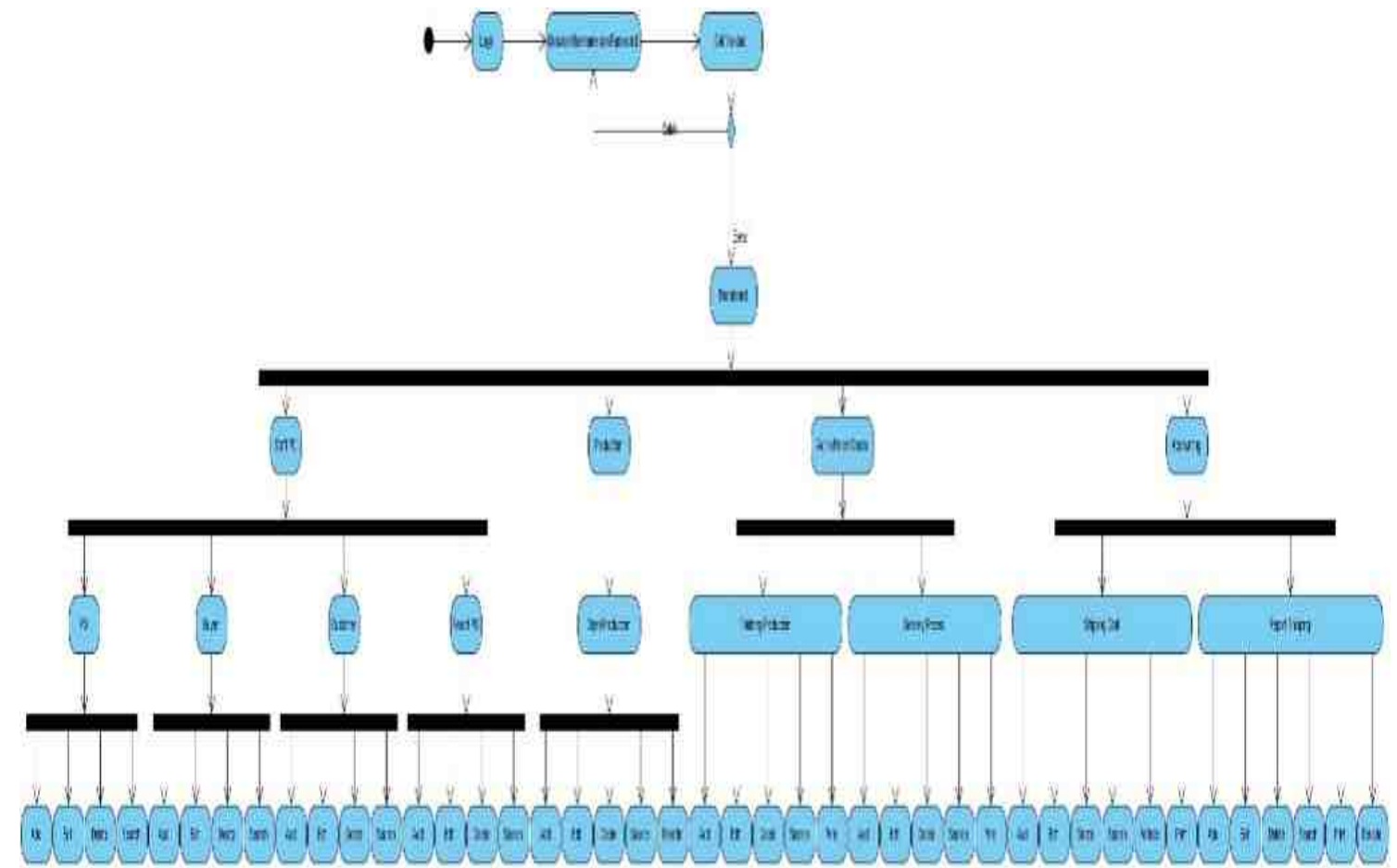

Gambar 2 Activity Diagram Usulan

Sequence Diagram Yang Di Usulkan pada bagian Staff PC

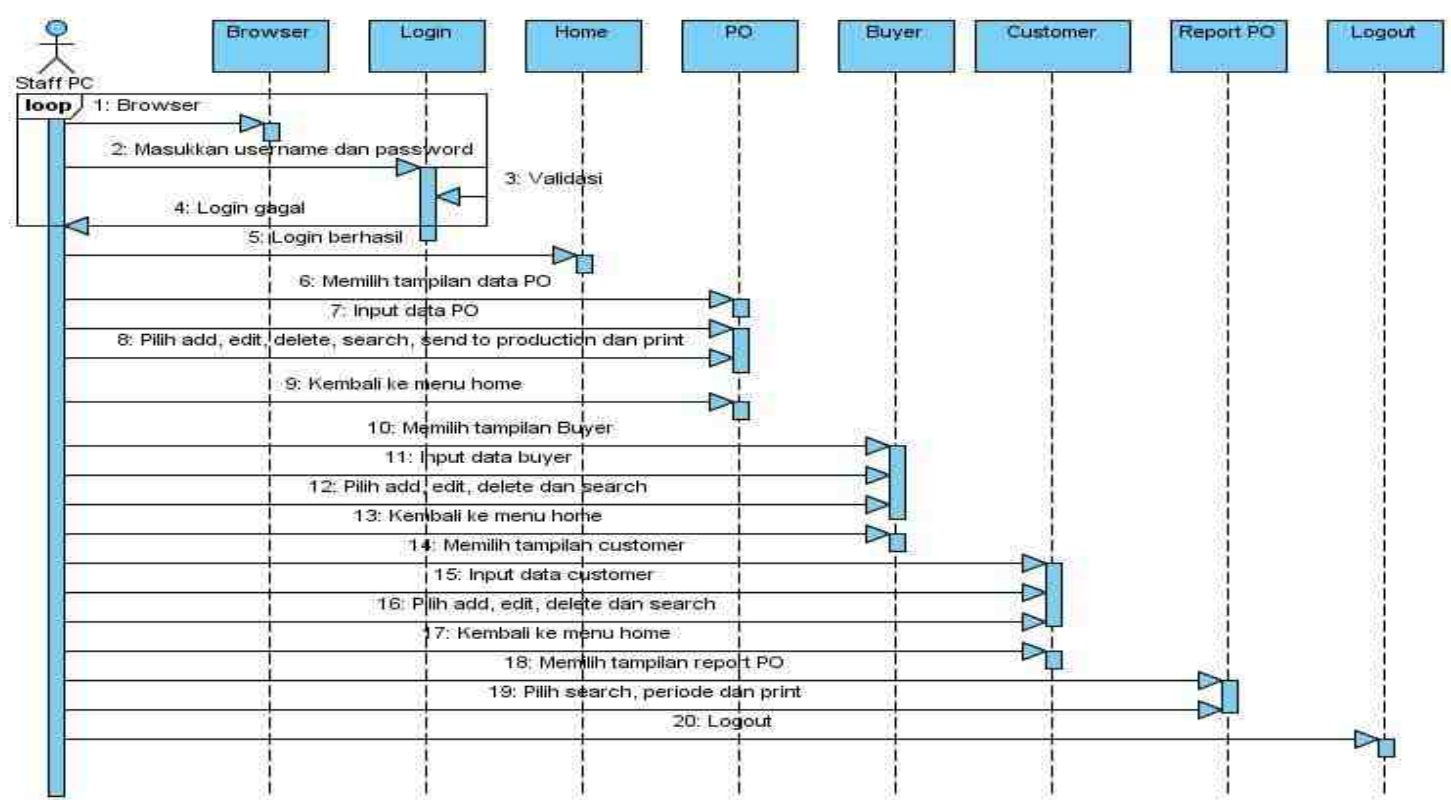

Gambar 3 Sequence Diagram Usulan pada bagian Staff PC 
Sequence Diagram Yang Di Usulkan pada bagian Production

$\square$

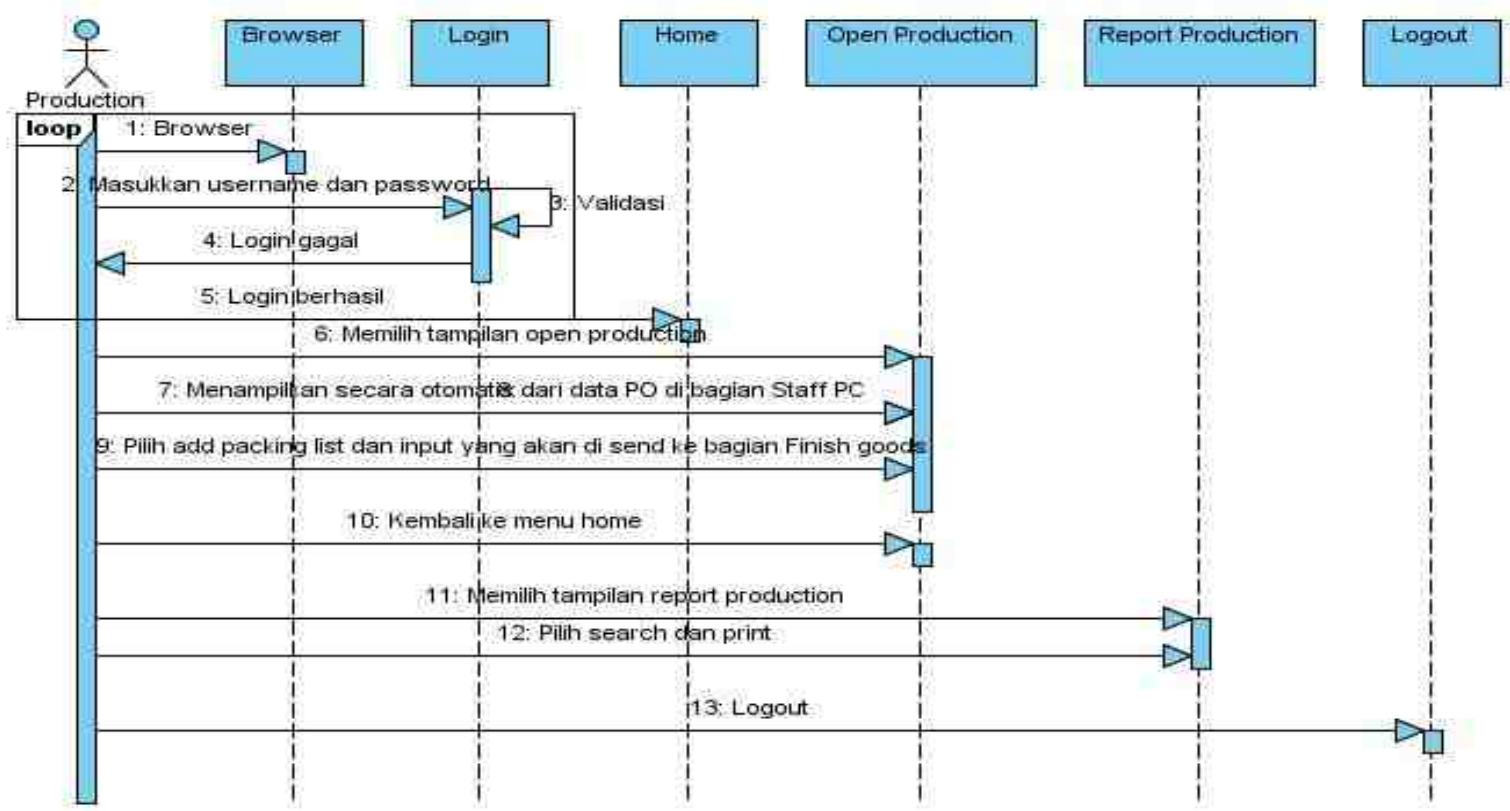

Gambar .4 Sequence Diagram Usulan pada bagian Production

Sequence Diagram Yang Di Usulkan pada bagian Admin Finish Goods

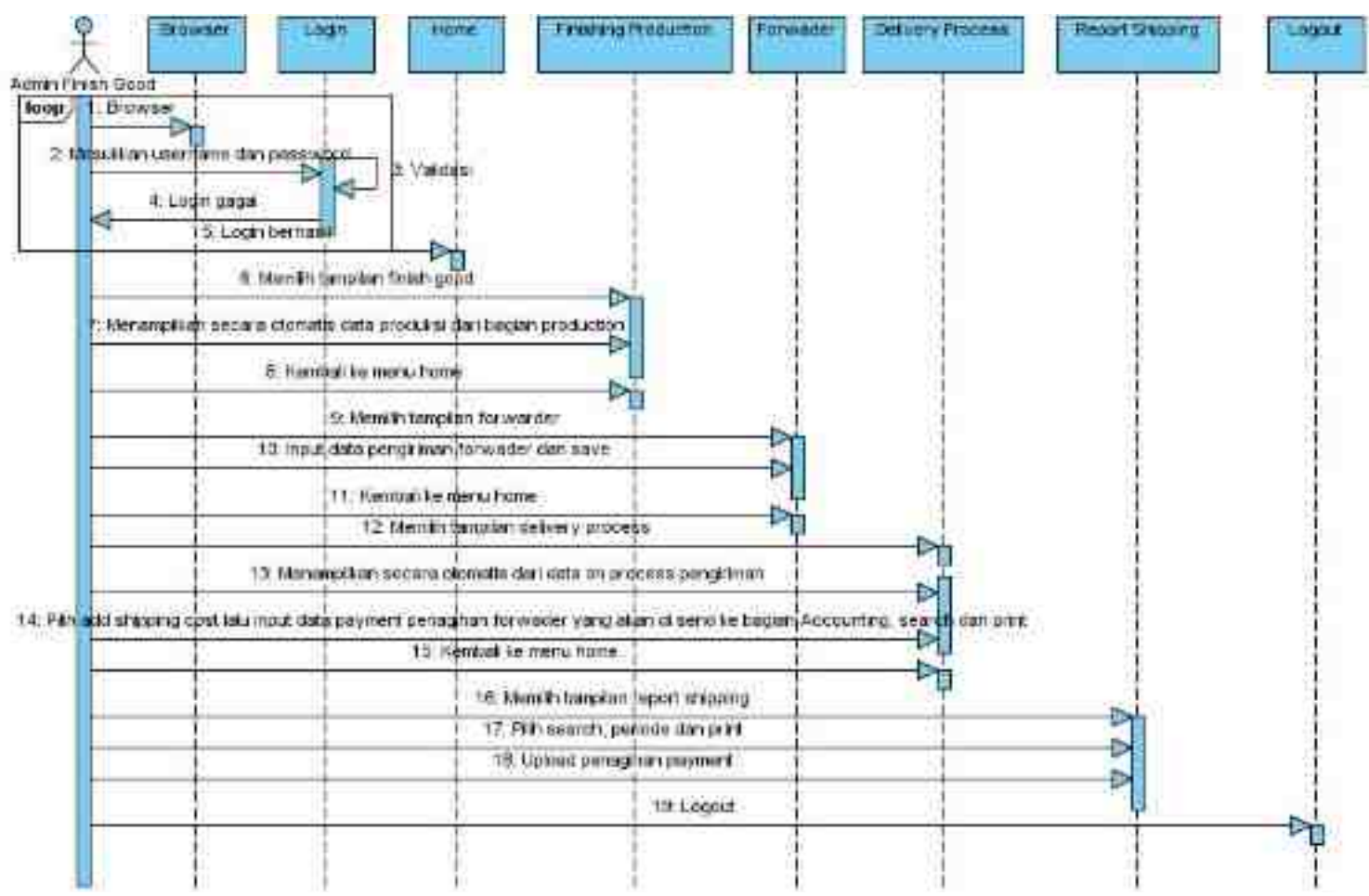

Gambar 5 Sequence Diagram Usulan pada bagian Admin Finish Goods 


\section{Sequence Diagram Yang Di Usulkan pada bagian Accounting}

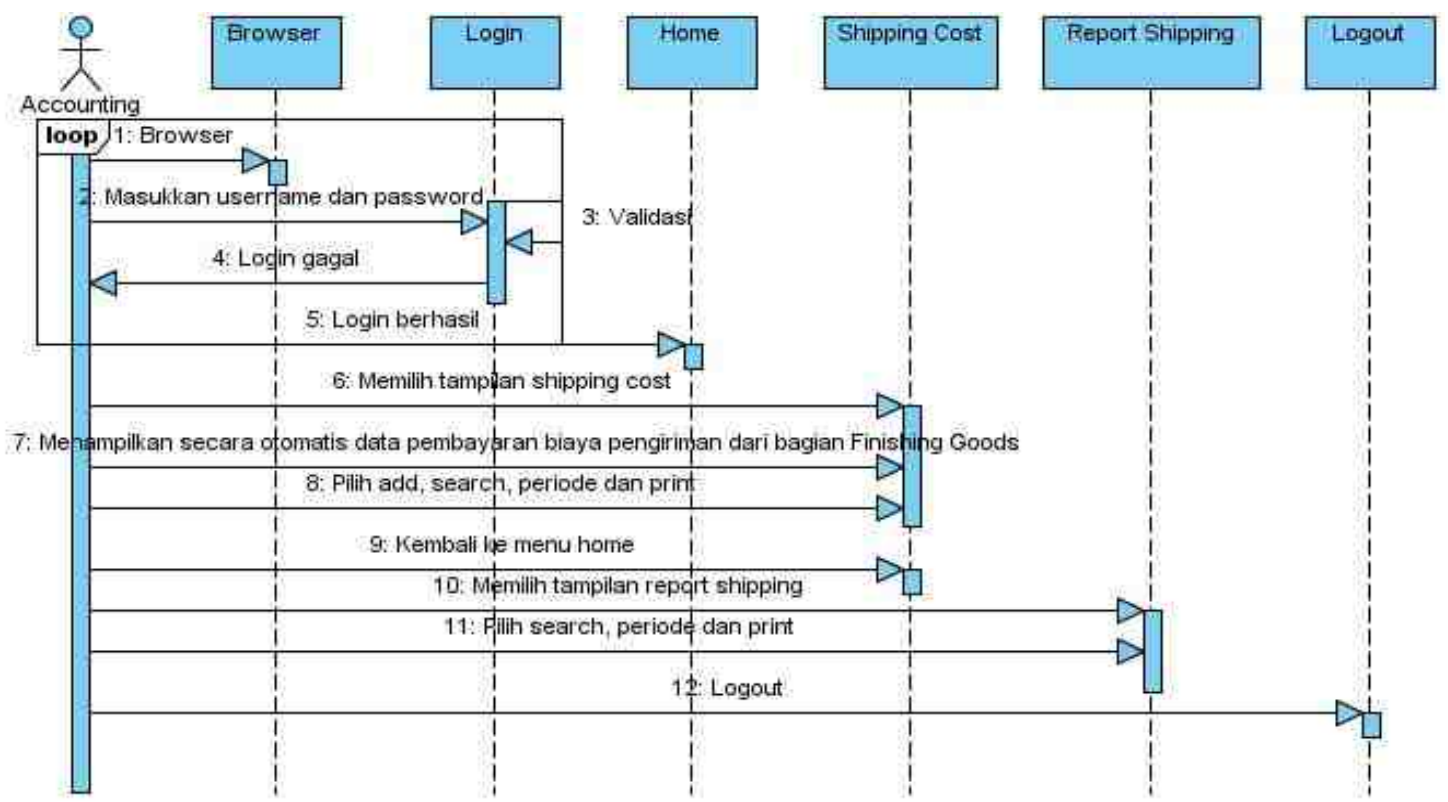

Gambar 6 Sequence Diagram Usulan pada bagian Accounting

\section{Class Diagram Yang Di Usulkan}

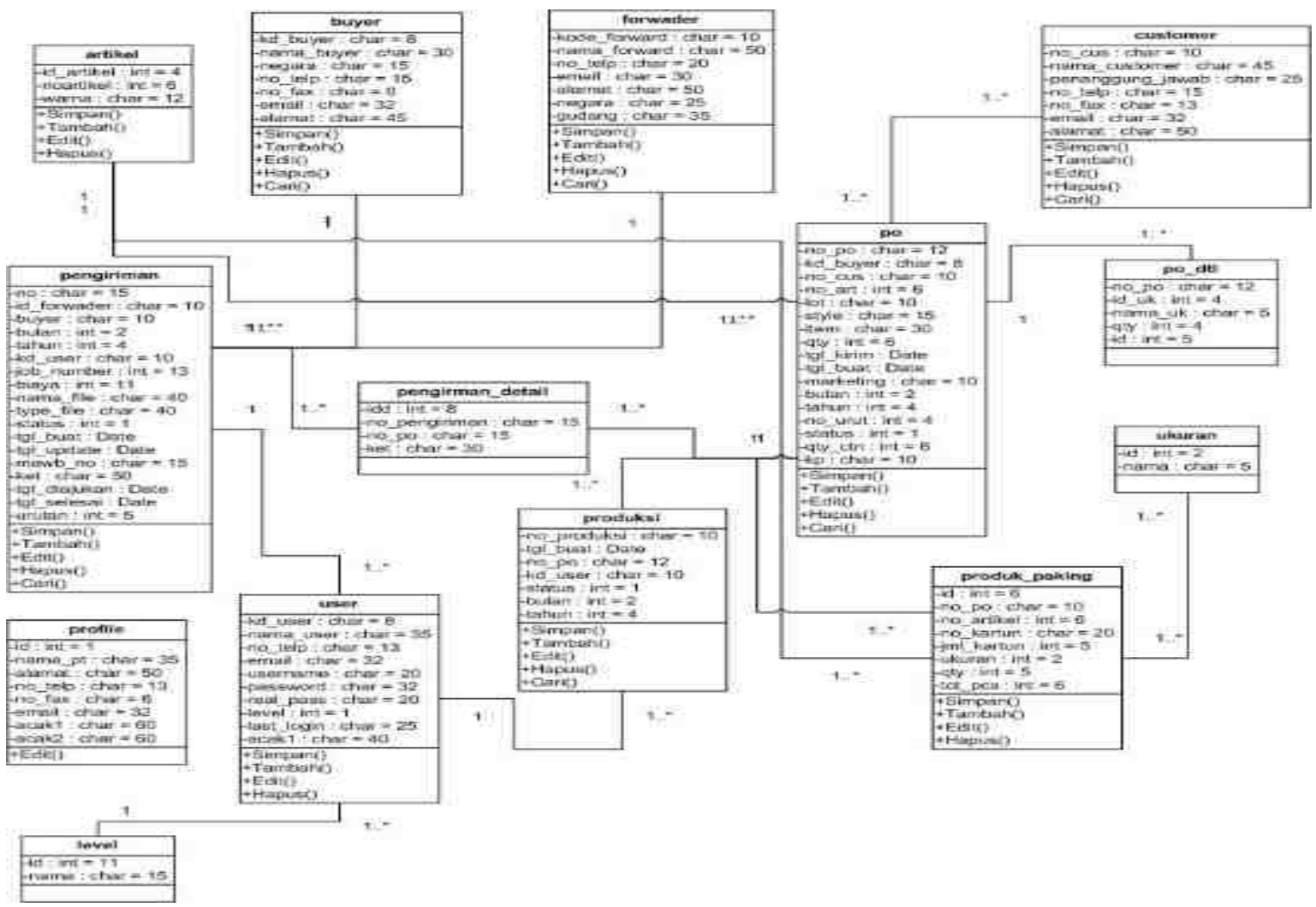

Gambar 7 Class Diagram Yang Di Usulkan 


\section{IMPLEMENTASI SISTEM}

1. Tampilan Menu Login

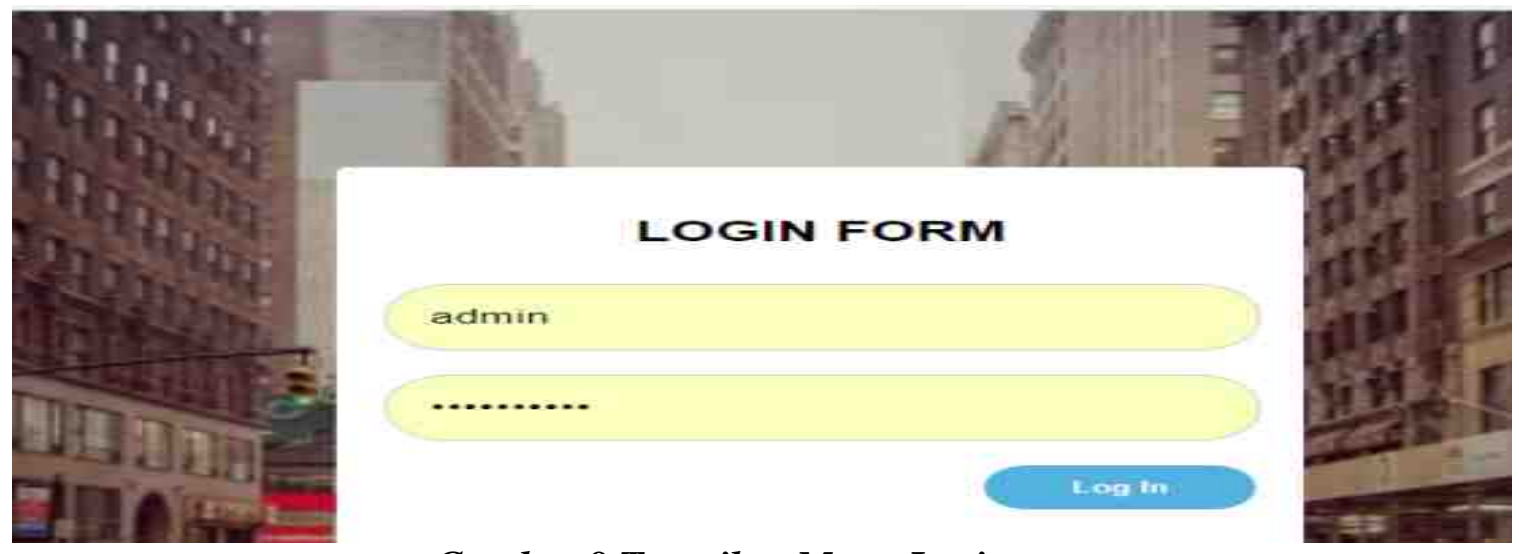

\section{Gambar 8 Tampilan Menu Login}

2. Tampilan Menu Staff PC

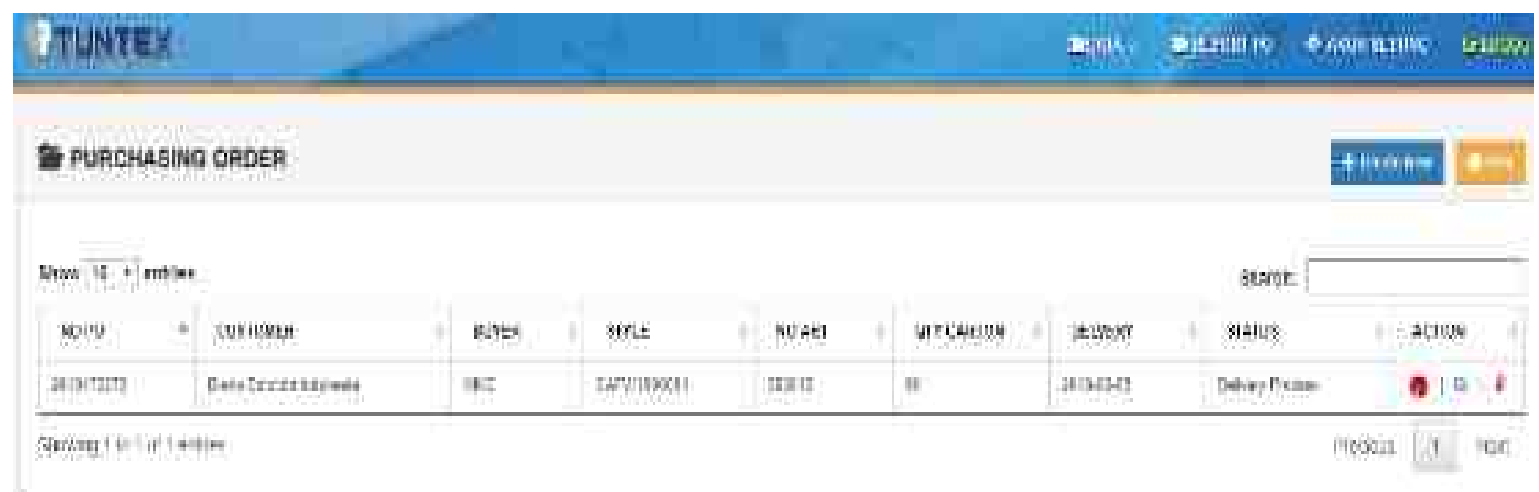

Gambar 9 Tampilan Menu PO

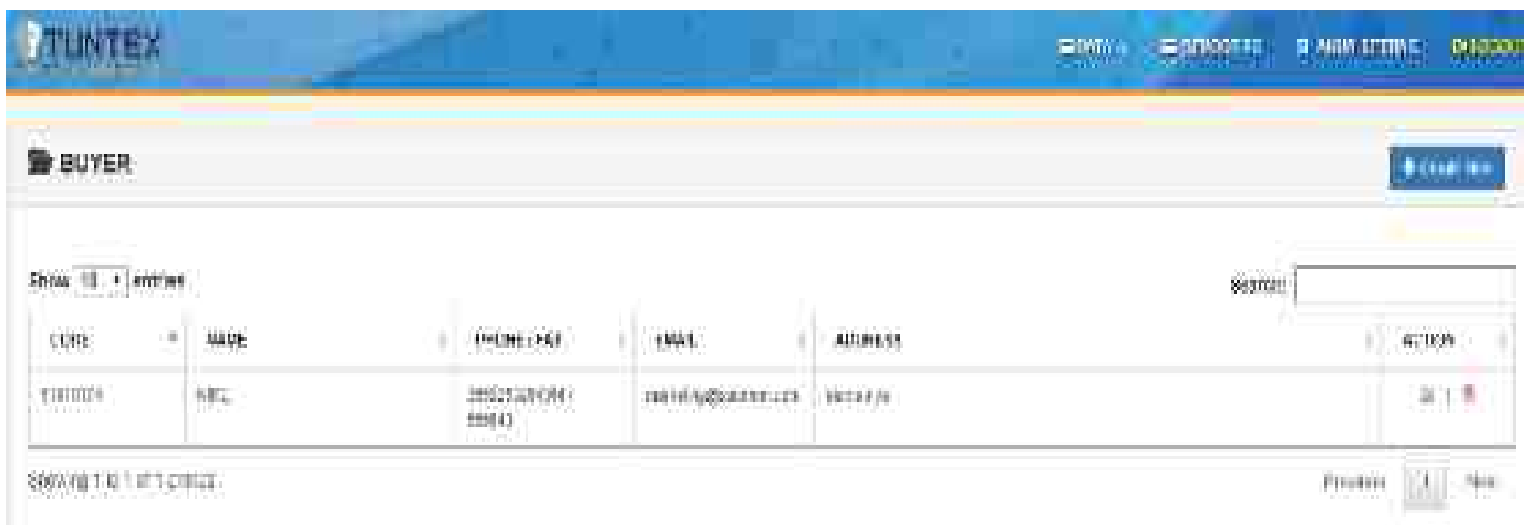

Gambar 10 Tampilan Menu Buyer 


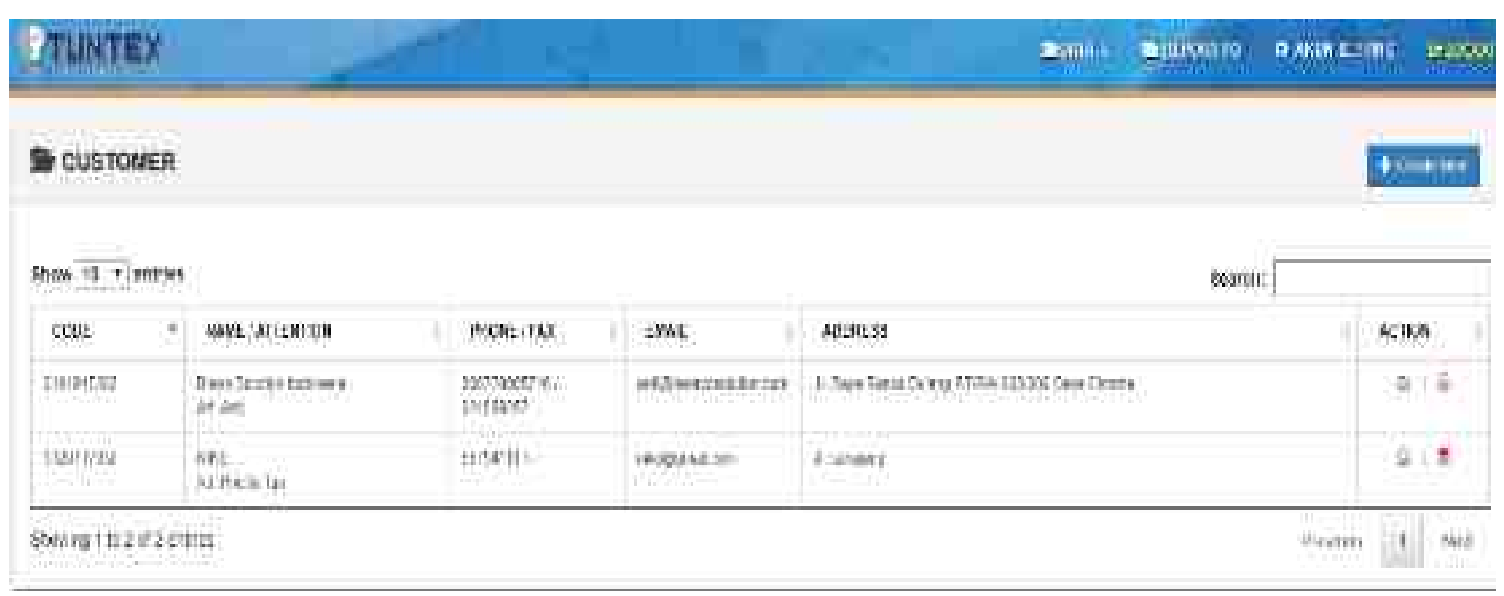

Gambar 11 Tampilan Menu Customer

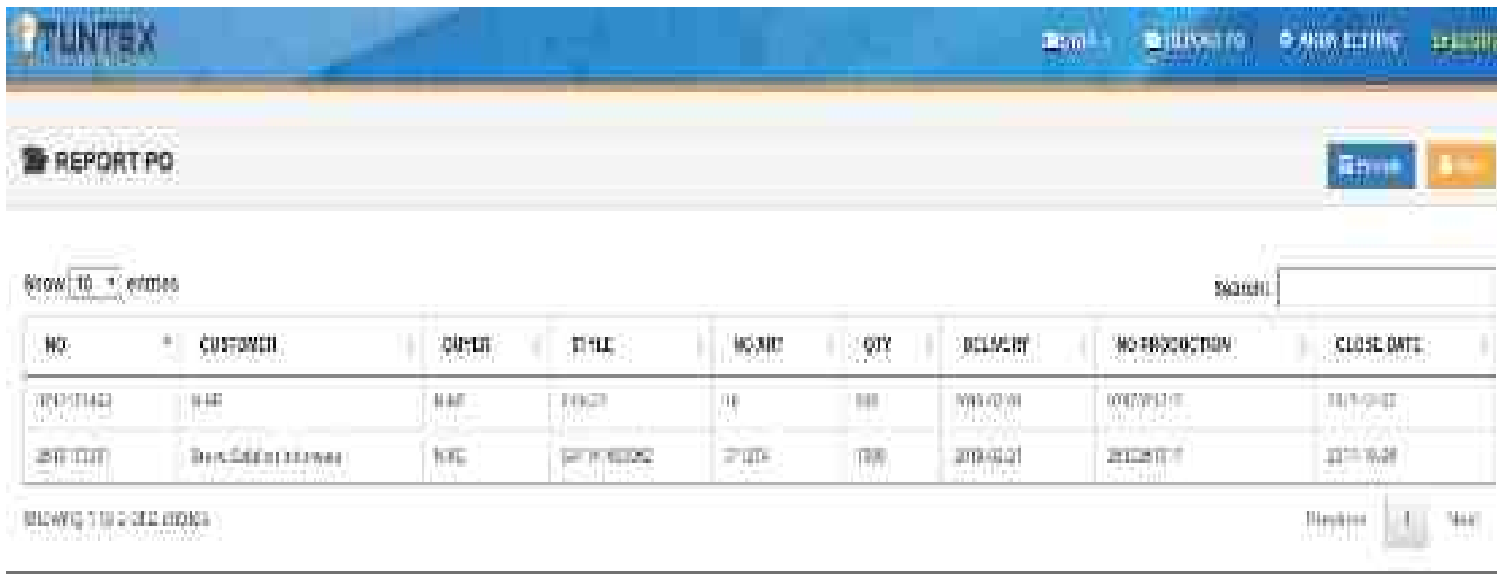

\section{Gambar 12 Tampilan Menu Report PO}

\section{Tampilan Menu Production}

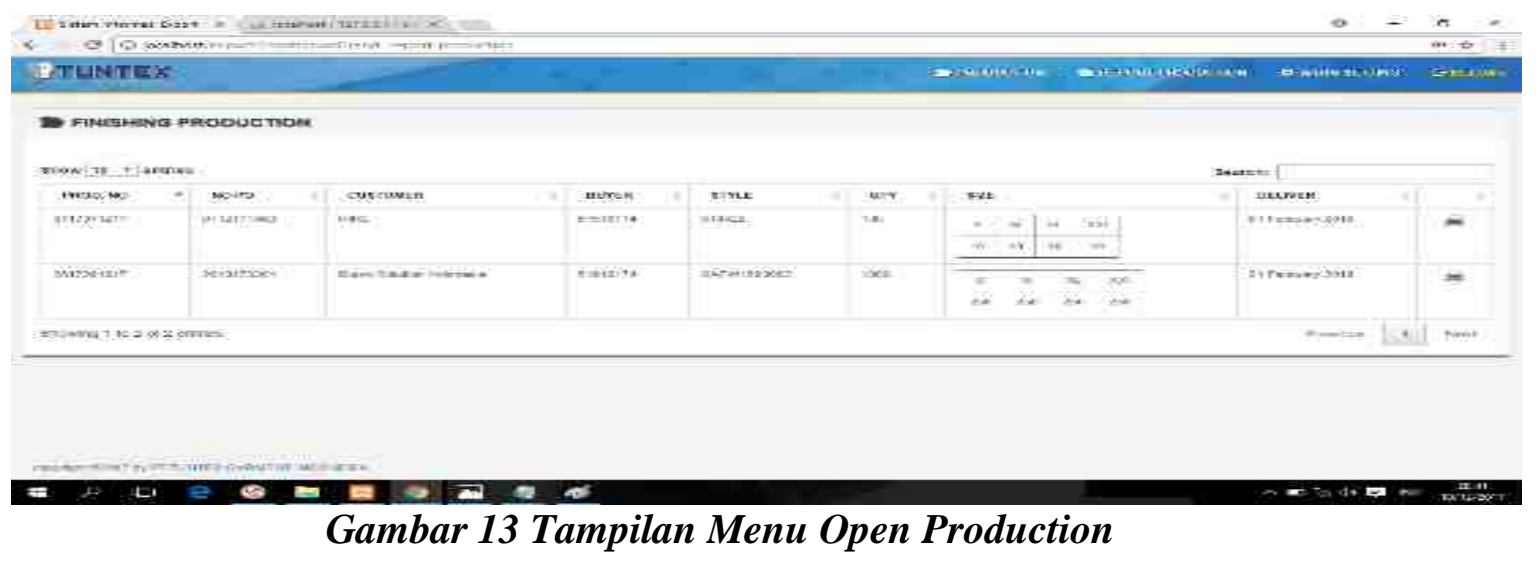




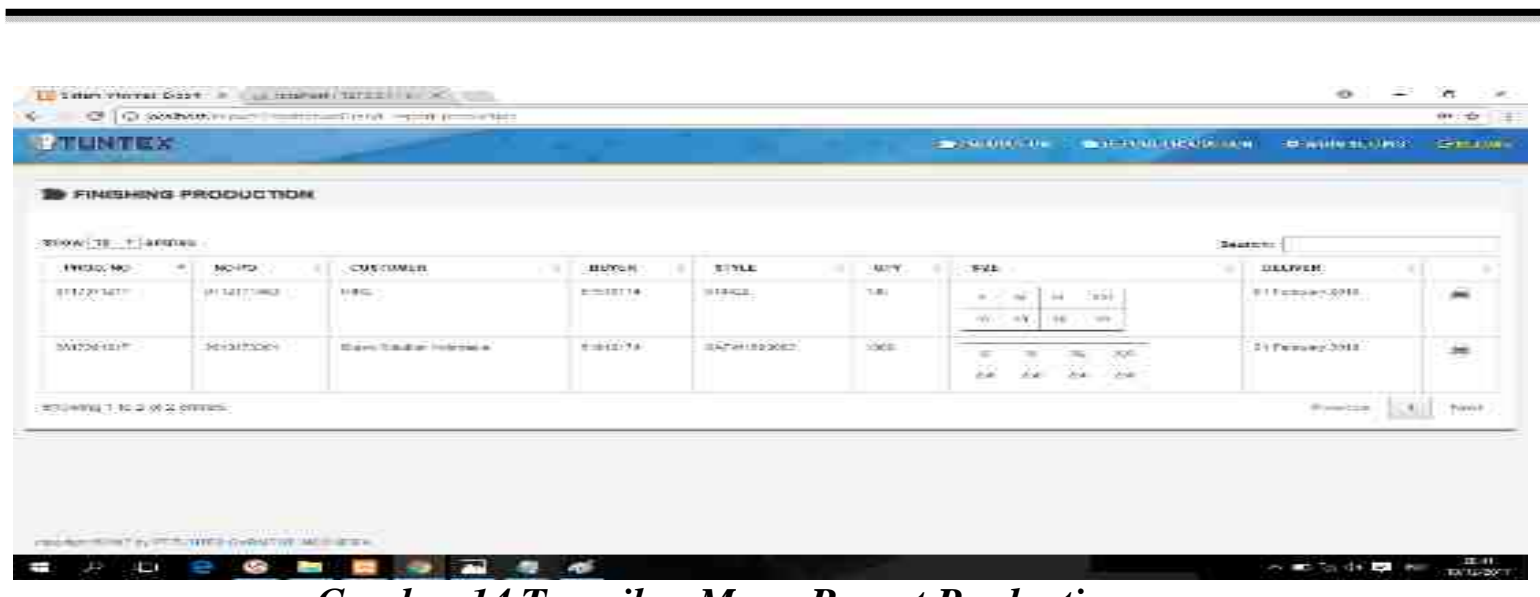

Gambar 14 Tampilan Menu Report Production

\section{Tampilan Menu Finish Goods}

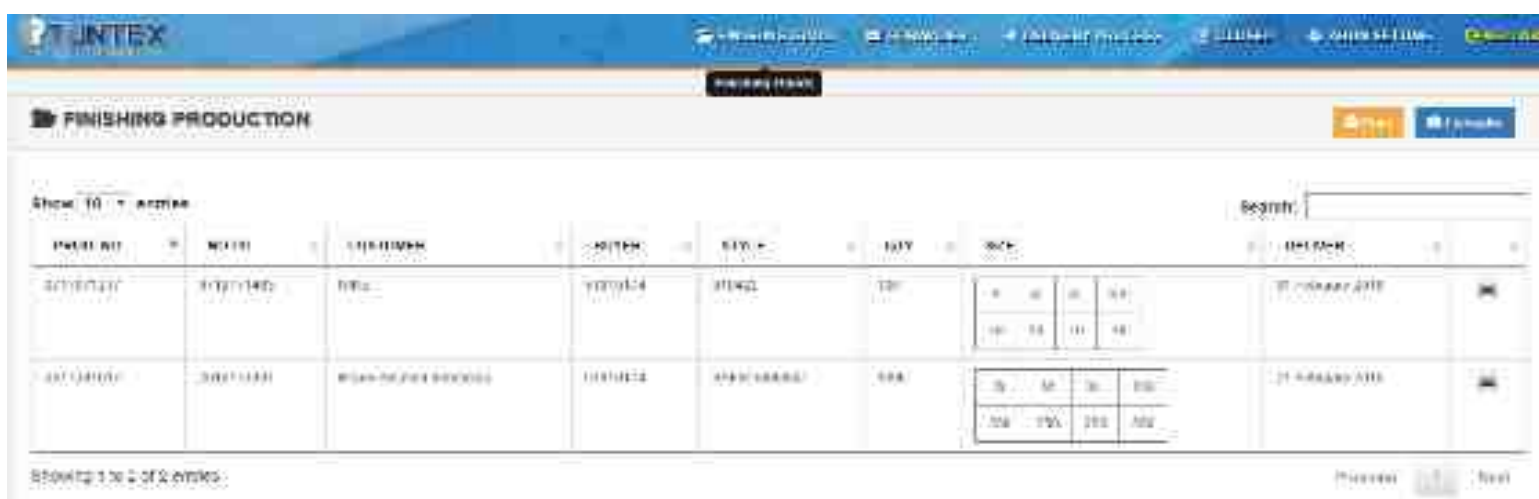

Gambar 15 Tampilan Menu Finishing Production

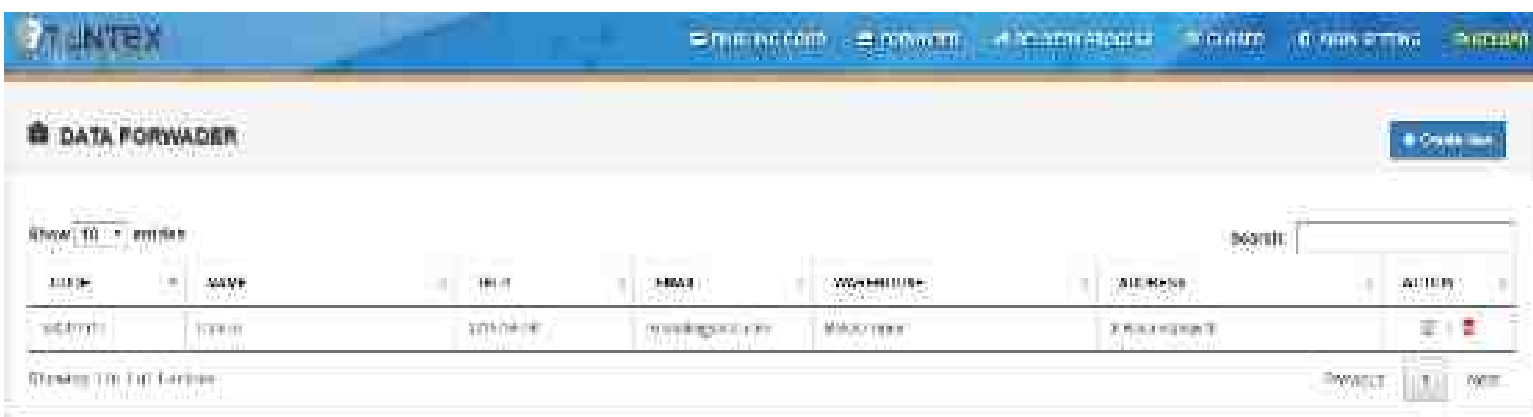

Gambar 16 Tampilan Menu Data Forwarder

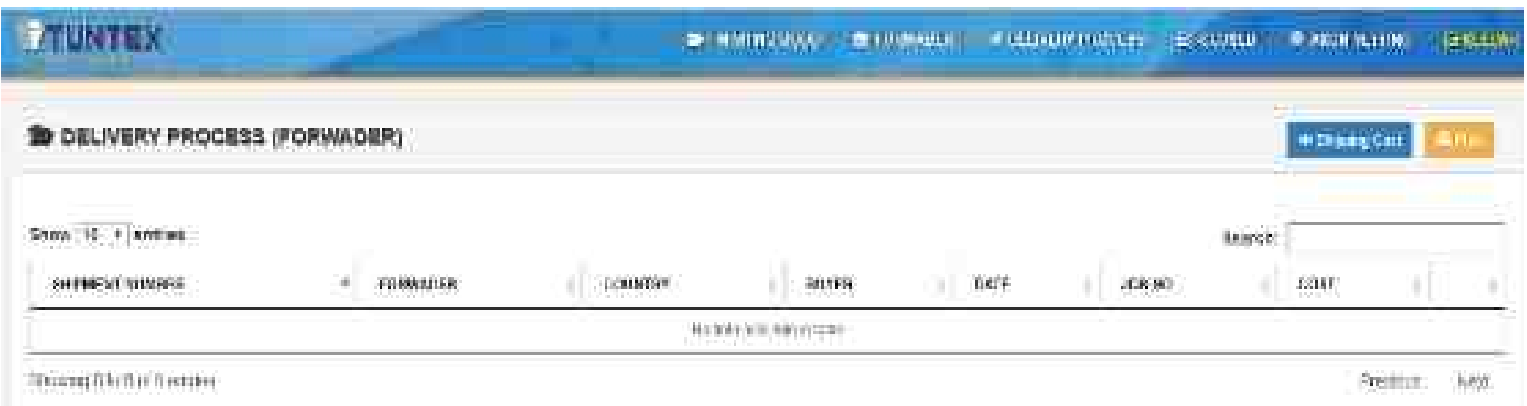

Gambar 17 Tampilan Menu Delivery Process 


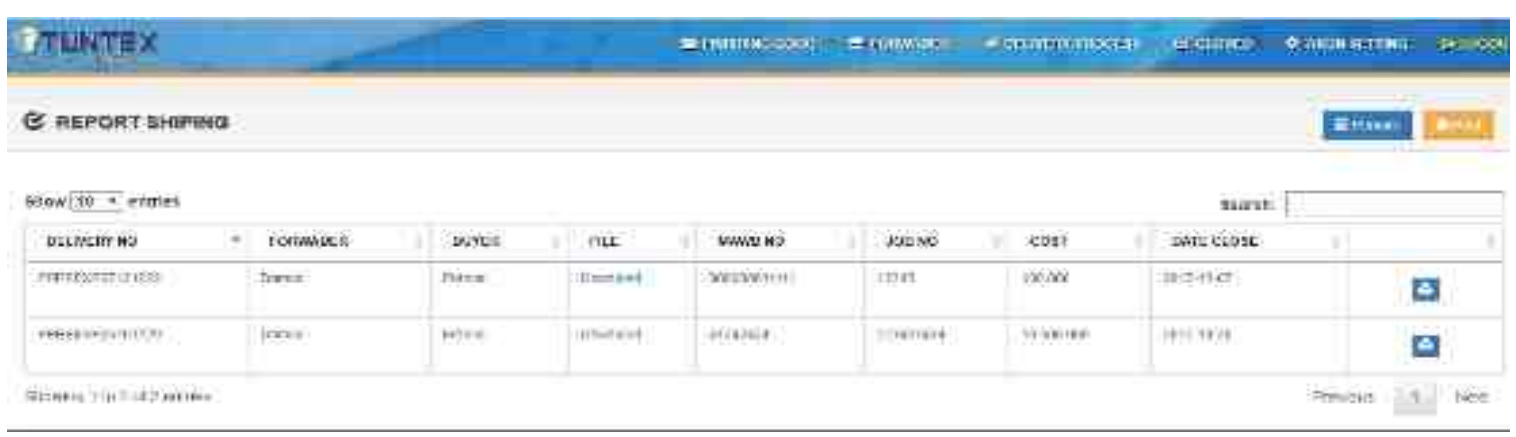

Gambar 18 Tampilan Menu Report Shipping

\section{Tampilan Menu Accounting}

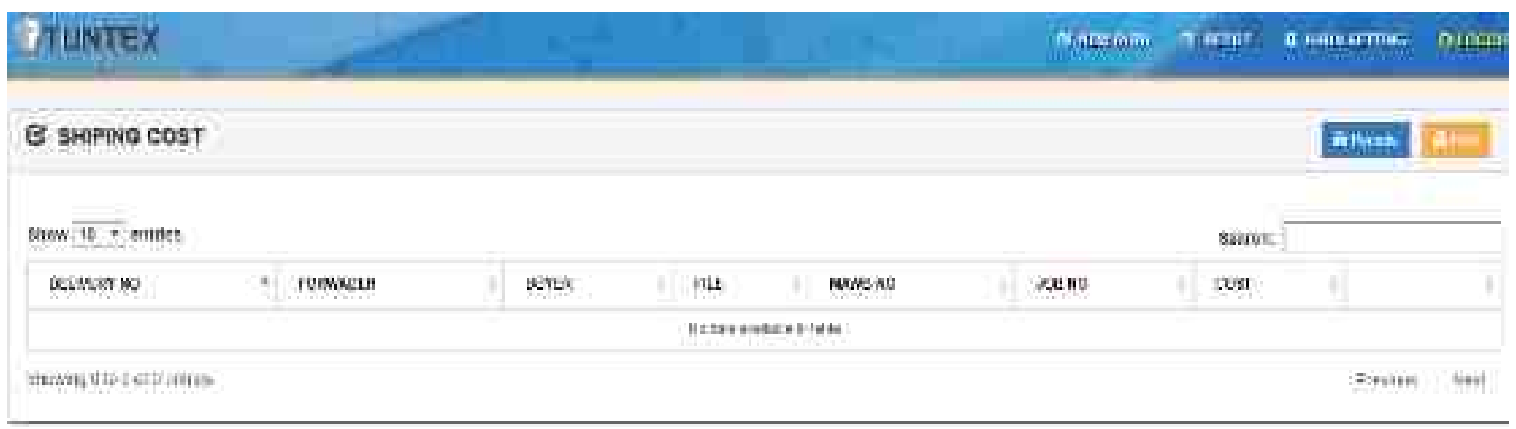

Gambar 19 Tampilan Menu Shipping Cost

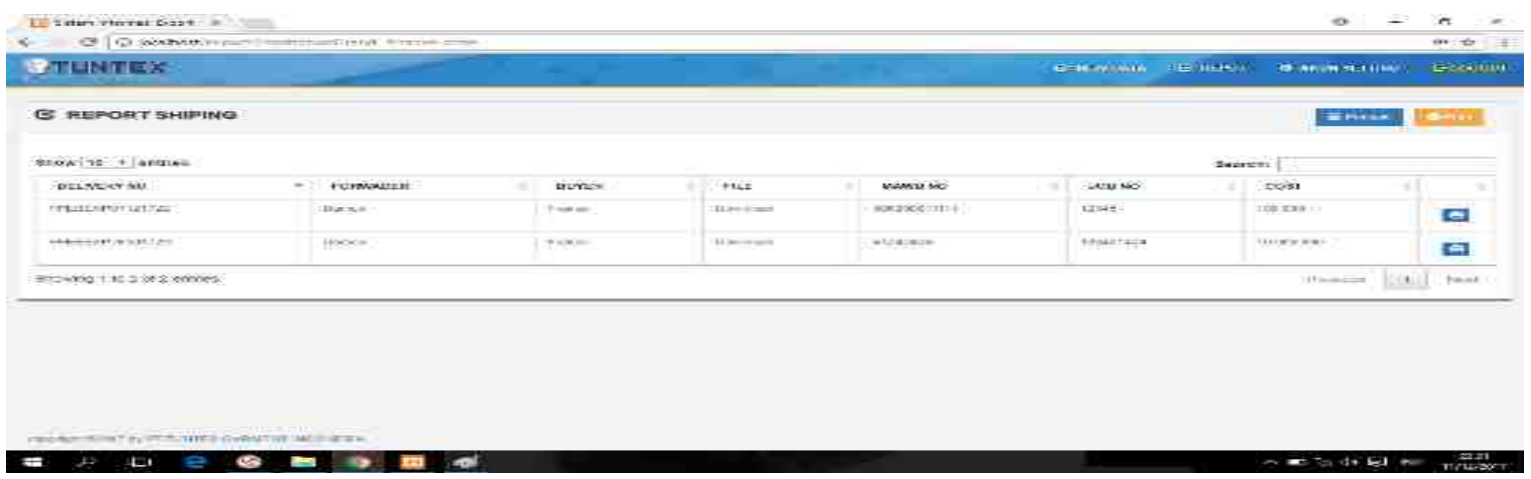

Gambar 20 Tampilan Menu Report Shipping

\section{KESIMPULAN}

Berdasarkan hasil penelitian ini yang telah dilakukan terdapat beberapa kesimpulan yang telah di ambil sebagai berikut :

1. Hasil pengamatan yang di dapat bahwa sistem informasi yang berjalan saat ini pada PT. Tuntex Garment Indonesia dalam proses penerimaan dan pengiriman barang ekspor yang dikelola oleh admin finish goods masih dilakukan secara manual dengan penginputan datanya ke dalam microsoft excel baik itu data penerimaan maupun pengiriman barang.

2. Kendala yang terjadi pada sistem informasi pengiriman barang ekspor yaitu hilangnya data dari dokumen penerimaan dan pengiriman barang ekspor dikarenakan banyak dokumen yang tertumpuk dan berantakan, proses pengelolaan data pun memerlukan waktu yang cukup lama. Oleh karena itu dengan menggunakan komputerisasi yang baik itu dengan adanya sistem berbasis web agar kendala yang dialami admin finish goods dengan mudah teratasi, cepat dan akurat sesuai tujuan yang diharapkan. 
3. Dalam mengambangkan sistem pendataan penerimaan dan pengiriman barang yang dapat meningkatkan kinerja admin finish goods dengan dirancangnya aplikasi berbasis web dimulai dari pengumpulan data, menganalisa sistem lama dan sistem baru dengan 1 metode yaitu metode analisa SWOT, perlu adanya elisitasi dalam mengumpulkan kebutuhan sistem, melalukan perancangan dengan fokus secara terstruktur data menggunakan database $M y S Q L$ dan detail (algoritma) procedural dengan menggunakan bahasa pemograman PHP yang berkolaborasi dengan XAMPP, dalam melakukan pengujian testing digunakan dengan metode black box testing, serta dibutuhkan juga penyimpanan data keahlian sumber daya manusia yang mampu menggunakan aplikasi yang dirancang sehingga laporan yang dihasilkan datanya lebih akurat.

\section{SARAN}

Seluruh tahapan yang dilalui dalam penelitian ini, terdapat beberapa saran, sebagai berikut :

1. Melakukan pelatihan kepada user yang bersangkutan seperti Staff PC, Produksi, Admin Finish Goods, Accounting dan Admin.

2. Agar sistem dapat berjalan dengan baik sehingga tidak adanya kejadian kesalahan yang akan dialami.

3. Apabila terdapat kekurangan pada sistem yang sedang diusulkan, hendaknya dicatat oleh user, hal itu ditujukan untuk perbaikan sistem agar tidak mengganggu kinerja kerja dan menjadi lebih baik.

4. Diperlukan juga pemeliharaan terhadap perangkat lunak (software) maupun perangkat kerasnya (hardware) demi kelancaran sistem.

\section{DAFTAR PUSTAKA}

[1] Mujiati, Hanik, Sukadi. 2013. “ Analisa Dan Perancangan Sistem Stok Obat Pada Apotek Arjowinangan. "Solo : UNSA. Indonesia Jurnal On Computer Science- Speed (IJCSS)FTI, Vol. 1.

[2] Aris, Dkk. 2016. “Aplikasi Sistem Informasi Simpan Pinjam Pada Koperasi Usaha Bersama Bank Syariah At-Tahwilm Kota Tangerang”. Yogyakarta : Jurnal Nasional Semnas Teknomedia Vol. 4 No. 1- Februari 2016.

[3] Tantra, Rudi. 2012. Manajemen Proyek Sistem Informasi. Yogyakarta : Andi.

[4] Murad, Dina Fitria, Kusniawati. Nia, Asyanto. Agus. 2013. Aplikasi Intelligence Website Untuk Penunjang Laporan PAUD Pada Himpaudi Kota Tangerang. Jurnal CCIT. Tangerang : Perguruan Tinggi Raharja. Vol. 7, No. 1, September 2013 